Volume 8, No.5, September - October 2019

International Journal of Advanced Trends in Computer Science and Engineering

Available Online at http://www.warse.org/IJATCSE/static/pdf/file/ijatcse49852019.pdf

https://doi.org/10.30534/ijatcse/2019/49852019

\title{
UMN Bulletin: User Interest Based Information Application
}

\author{
Samuel $^{1}$, Seng Hansun ${ }^{2}$ \\ ${ }^{1}$ Informatics Department, Universitas Multimedia Nusantara, Tangerang, Indonesia, samuel@ student.umn.ac.id \\ ${ }^{2}$ Informatics Department, Universitas Multimedia Nusantara, Tangerang, Indonesia, hansun@umn.ac.id
}

\begin{abstract}
The dissemination of information through technology promises an opportunity to increase speed and work efficiency. However, with the abundance of information does not necessarily make it easier to get information. Therefore, an application to provide information based on user interest was studied in this research. Information recommendation is derived using the Weighted Sum Model (WSM) method which has the ability to assess more precisely based on predetermined criteria and preference weights. Interest theory used in this research is the Holland Codes which states that humans have six types of interests, namely realistic, investigative, artistic, social, enterprising, and conventional. The application built had been tested for Universitas Multimedia Nusantara students and administrators (i.e. Student Affairs and Public Relations of Student Executive Board) based on End-User Computing Satisfaction (EUCS) method. Based on the research results, the value of user satisfaction is $79.87 \%$ which means that it can satisfy the users' needs.
\end{abstract}

Key words: Information, Interest, WSM, Holland Codes, UMN.

\section{INTRODUCTION}

In the field of information dissemination, the application of technology promises an opportunity for efforts to increase speed and work efficiency [1]. Media technologies are used in the dissemination of information in the form of computers, telephones, televisions, electronic home appliances, and handheld devices (mobile phones). Dissemination of information through technology cannot be separated from the role of the internet used as a data search center in the world. According to data from the "Asosiasi Penyelenggara Jasa Internet Indonesia" (APJII), the number of internet users recorded in 2016 reached 132.7 million people or $51.8 \%$ of 252.4 million of Indonesia citizen [2].

Dissemination of information to Universitas Multimedia Nusantara (UMN) students will be more effective when through a smartphone. This is based on the research that has been done by Prestianta and Nusantara [3] that is as much as 98\% of UMN students use the smartphone as a mobile device rather than a tablet or feature phone. Also, UMN students can spend between 3-7 hours when used it. One of the information dissemination through a smartphone that has been done is the
UMN Bulletin application.

Based on a non-formal interview with Deborah Megan, as the coordinator of Public Relation Division of Student Executive Body (BEM) of UMN, in a month there are more than 20 posters entered and recorded in a logbook. This figure is not included plus information published by the UMN Student Affairs division. It will help students in obtaining the required information. However, with the abundance of information does not necessarily make it easier for students to get information that suits their interests. Various information about student activities have been disseminated through email, but in the implementation sometimes the information sent was accumulated from one to another so that the information is not readable by UMN students. Aryo Gurmilang as Student Development staff, also stated that an application is not only limited to displaying information but the information must be based on Student Identity Number (NIM), needs and interests of students who log in. With this feature makes students want to $\log$ in and use the application, due to the emergence of information notification based on interest. Citrandika Selarosa as Manager of Internal Student Affair said that there is needed a portal or application that can display various information.

Recommendation system is software that aimed at helping users by providing recommendations when users are faced with large amounts of information [4]. Kenteris et al. [5] state recommendation system in providing recommendation based on filtered information. Commonly used methods in recommendation systems include collaborative filtering and content-based filtering. However, the method of collaborative filtering and content-based filtering cannot provide maximum results to obtain recommendation information. Therefore, to obtain maximum results then in the application is applied a Multi-Criteria Decision Making (MCDM) method. According to Adomavicius et al. [6], MCDM can help improve the quality of the recommendations as this method can show more complex references from everyone. One method of MCDM is the Weighted Sum Model (WSM), which is a method that combines several different criteria, in which each criterion has certain weights to produce a single result value on each alternative so that each alternative can be compared to each other [7]. Based on previous research, the advantages possessed by the WSM method compared with other models is that WSM has the ability to conduct assessments more precisely because it is based on predetermined criteria and weight value preference [8-11]. Given the ranking process after determining the value for each alternative, WSM can select the best alternative from a number of alternatives [12]. This is supported by Nugroho's statement [13] which states that WSM is one of the most popular and well-known MCDM 
methods.

Based on existing problems, the development of UMN Bulletin application is done by implementing a Weighted Sum Model (WSM) method to get information based on student interest.

\section{RECOMMENDATION SYSTEM}

Recommendation system is software intended to help users by providing recommendations when users are faced with a large amount of information. Recommendations given to users are expected to assist in making decisions [4], such as what products to buy, music to listen to, or news to read. It could also help to produce the TV self-promotion schedule [14] and loan credibility prediction system [15].

In making the recommendation system, there are several approaches used [4], among others:

- Content-based

- Collaborative-filtering

- Demographic

- Knowledge-based

- Community-based

- Hybrid Recommender Systems

However, these six approaches are not suitable to provide recommendations that have many criteria. Berka and Plößnig [16] suggest the chosen approach depends on the problem to be solved, the computational resources for the recommendation component, and the objective of an application. Therefore, some researchers try to introduce approaches to recommendation systems, one of which is the Multi-Criteria Recommender System [6].

\section{WEIGHTED SUM MODEL}

WSM is one of the popular MCDM methods and has a good accuracy result. Weighted Sum Model also is known as Simple Additive Weighting or Scoring Method is a method often used in Multiple Attribution Decision Making (MADM) technique $[17,18]$. Alternative options are obtained based on some decision-making criteria [13]. According to Nugroho and Ferdiana [19], there are two terms in MCDM that are alternatives which present the choices of actions that can be taken by decision-makers and attributes which are the criteria of an alternative.

$$
A_{i}^{W S M-S c o r e}=\sum_{j=1}^{n} w_{j} a_{i j}, \text { for } i=1,2,3, \ldots, m
$$

$A_{i}^{W S M-S c o r e}$ is the final value of each alternative $A_{i}, w_{j}$ is the relative weight of the criterion $C_{j}$, while $a_{i j}$ is the performance value of alternative $A_{i}$ with criterion $C_{j}$.

In WSM calculations, the component facing the end of the WSM is the criterion weight and performance of each alternative for each attribute. The result of the criteria. The formula used for normalization is as follows:

$$
\text { Normalization Value }=\frac{\text { Value }}{\text { Total Value }}
$$

In addition to the criterion weight, before the calculation using Equation 1, the performance value of each alternative for each criterion was first normalized using Equation 3.

$$
a_{i j}=\frac{\text { attribute value }}{\text { maximum value }}
$$

\section{HOLLAND THEORY}

One theory used to categorize interest is Holland's theory. This theory is basically used for career testing. However, in its implementation, Holland's theory provides a sense of personal pleasure orientation supported by an appropriate work environment that will determine individual lifestyle choices [20].

Brown explains that Holland's theory is divided into six types and is better known as RIASEC Holland Theory or Holland Codes, which consists of [21]:

- Realistic

Some characteristics of this type are to give priority to muscle strength, physical skills, strong motor coordination, care for animals, and likes to tools.

- Investigative

Some characteristics of this type are like for problem-solving, mathematical, and critical thinking.

- Artistic

Characteristics of this type are like to the activities of art, music, writing, and expressive skills.

- Social

Characteristics of this type are like the activities associated with helping people, like to interact with others, and easy to communicate.

- $\quad$ Enterprising

Characteristics of this type are like to meet with others, likes to persuade others, and creative.

- Conventional

Characteristics of this type are like working in the room, like an accurate job, and people who think of everything before acting.

\section{SYSTEM DESIGN}

The architecture of the implementation of Weighted Sum Model method in the UMN Bulletin application in displaying information according to the student interest is shown in Figure 1. In this system there are two main parts. The first part is UMN students as users who input the weight of each type of interest through mobile devices using the Android-based operating system. The second part is the administrator as the user who inputs the value of any alternative information that exists through the content management system owned by UMN Bulletin.

When a piece of information is about to be published, the administrator is required to fill in the value of each alternative. In this research is information from UMN affairs field, to every criterion of interest. Then, through the Application Program Interface (web service) UMN Bulletin application, on each UMN student's Android, will be taken weight of interest that has been filled by students. The system will 
calculate the value of information on the weight of each interest that UMN students have specified and normalized using the formula of the Weighted Sum Model (WSM) method. Having obtained the value of information that has been normalized, the value of information on each type of interest summed and the information will be sorted from the largest alternative value to the smallest. UMN students will receive an informed recommendation on the UMN Bulletin application interface on Android.

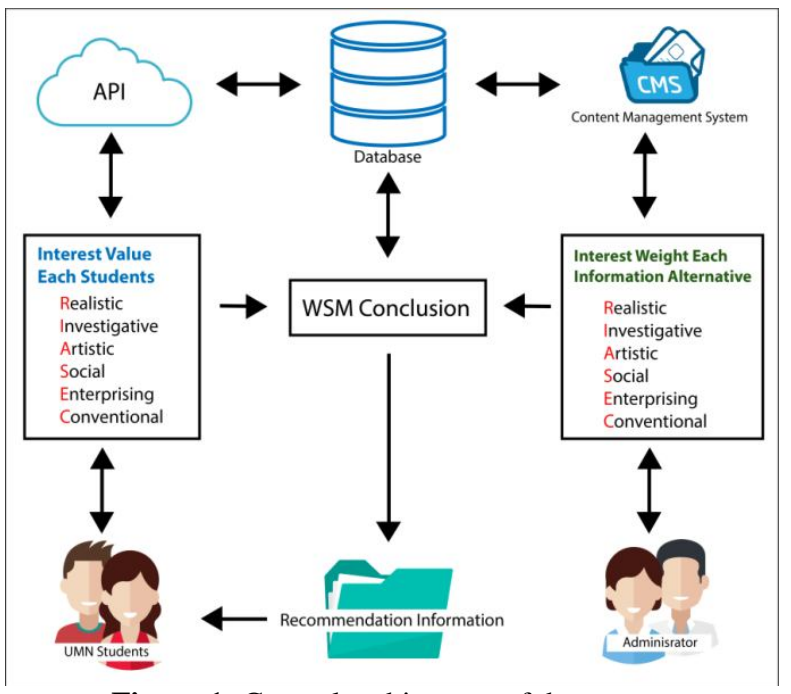

Figure 1: General architecture of the system

Figure 2 shows the calculation phases in determining the information recommendation using the Weighted Sum Model (WSM) method in the UMN Bulletin application.

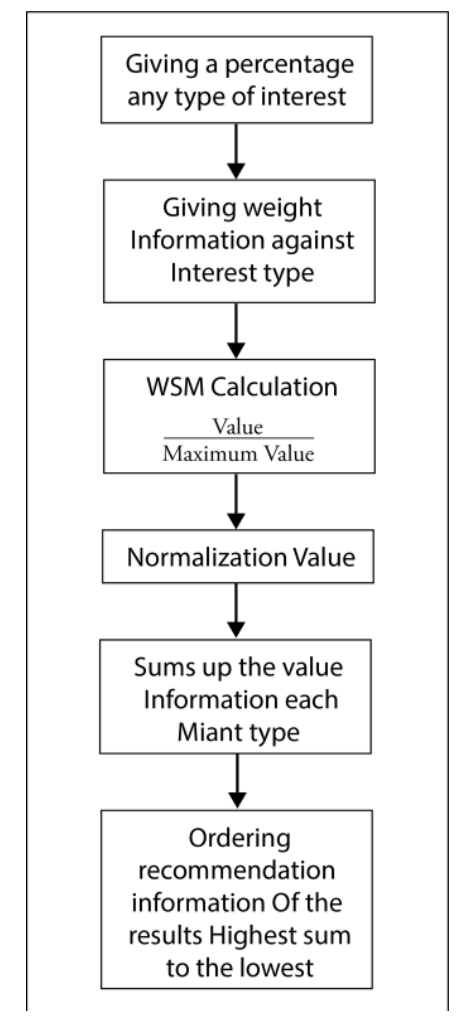

Figure 2: Block diagram of the recommendation system
Examples of Weighted Sum Model (WSM) implementation methods for displaying information recommendations on UMN Bulletin applications based on Fig. 2 are as follows:

- The first stage is to determine the percentage of each student's interest in the Android app based on Holland's theory. According to Holland's theory, humans have six types, namely, Realistic, Investigative, Artistic, Social, Enterprising, and Conventional. So, the attributes used in the recommendation of this information amount to six as shown in Table 1.

Table 1: Information recommendation attribute

\begin{tabular}{l}
\hline Attribute \\
\hline Realistic \\
Investigative \\
Artistic \\
Social \\
Enterprising \\
Conventional \\
\hline
\end{tabular}

After getting the weight of each interest, the weight is then normalized. Normalization is done by using (2).

- The second stage is to determine the value of each alternative to each attribute. The alternative in this research is student information. The scoring of each alternative uses a five-level Likert scale. The Likert scale variable and the value used can be seen in Table 2 .

Table 2: Likert scale of information value

\begin{tabular}{ll}
\hline Variable & Value \\
\hline Very Unsuitable & 1 \\
Unsuitable & 2 \\
Less Suitable & 3 \\
Suitable & 4 \\
Very Suitable & 5 \\
\hline
\end{tabular}

After determining the performance value of each alternative, next is to determine the maximum value of each attribute of all alternatives.

- The third stage is to do the WSM calculation. The WSM calculation begins by dividing the alternate value of each attribute by the maximum value of each attribute, using Equation 3.

- Furthermore, the performance value of each alternative is normalized, that is to multiply the value of each alternative to each attribute with the weight of each attribute that has been entered by the student. The formula used for the calculation is Equation 1.

- After doing the calculation of the results of each multiplication then summed to get the final value of the information.

- The last stage is to sort the alternative data from the largest value of information to the smallest.

\section{RESULTS AND ANALYSIS 6.1 Implementation Results}

Fig. 3 shows the New Interest page. On this page, users can define their interests in three ways. The first way is to move 
the circle on the Slider component to the right to zoom in and to the left to decrease the weight of interest. The second way is to write the weight on the TextEdit component; the weights should be written with a range of 0 to 100 . The third way is to test user's interest.

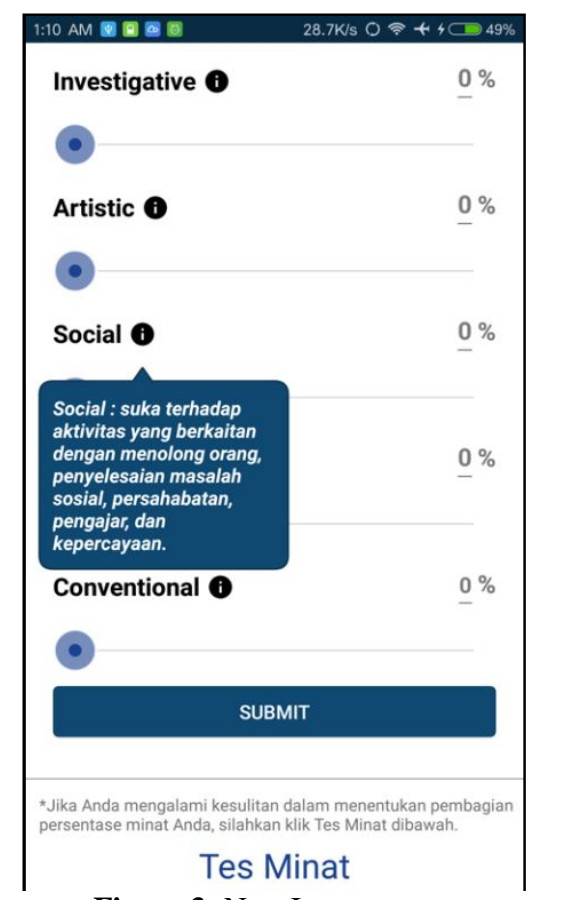

Figure 3: New Interest page

The interest test in Figure 4 consists of several statements to choose from. After selecting a statement that suits him, the user can press the Submit button to save the test results.

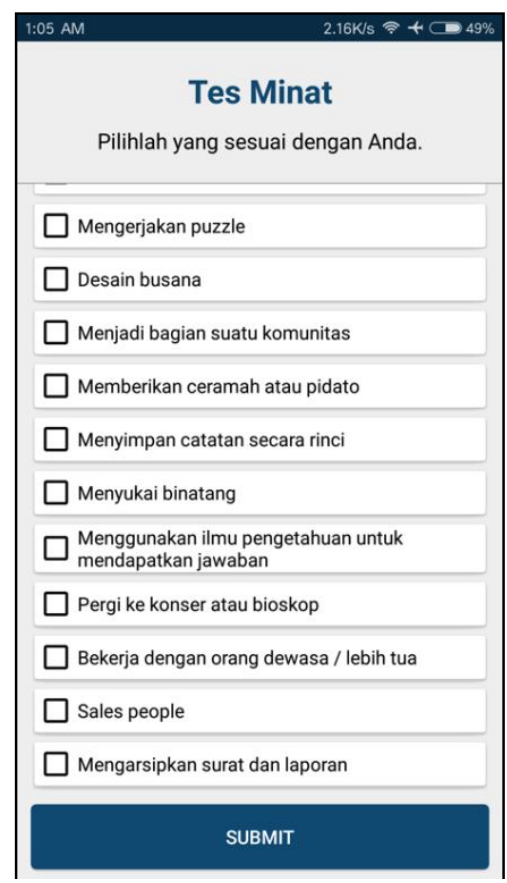

Figure 4: Interest Test page

Figure 5 shows the view of the Recommended Information page. This page is the main page of the UMN Bulletin app, where on this page there is campus regulatory information at the top of the page and student information recommendations at the bottom. The campus rules are shown in the form of a walking image that will feature all of the campus regulatory posters.

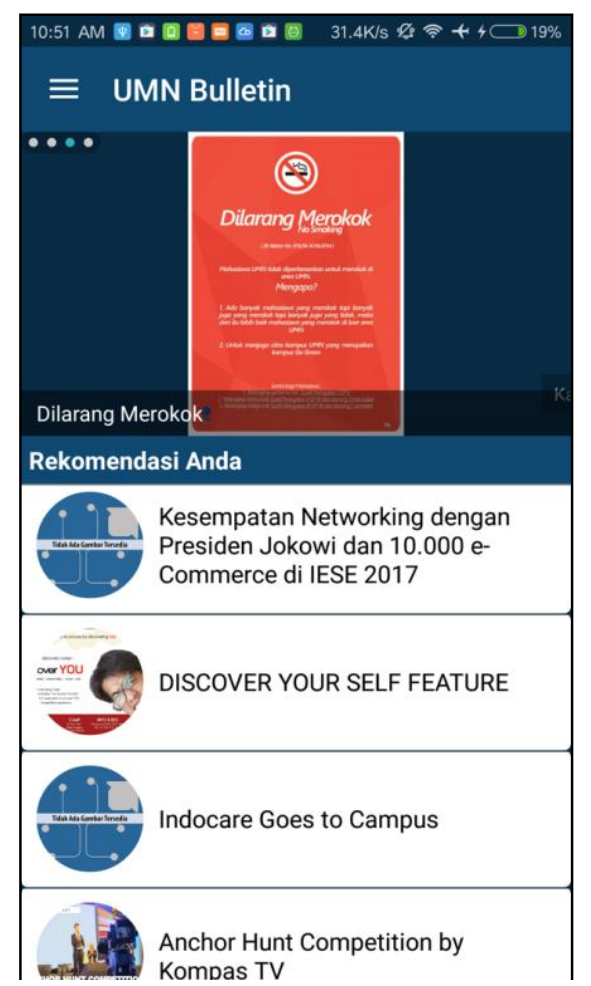

Figure 5: User Interest-based Information page

\subsection{System Evaluation}

The testing of the Weighted Sum Model (WSM) method implementation in the mobile application was done to 156 students of Multimedia Nusantara University (UMN) with minimum number of each faculty is 30 people. This is based on Roscoe's explanation in Sugiyono as cited in [22], which says if the sample is divided into some groups, then the total sample size for each group is at least 30 . Testing of mobile application is done by way of field study that is the student tried the mobile application on hand. After trying the application, the students were assessed by filling out a digital questionnaire.

The questionnaire used aims to obtain user satisfaction from the implementation of recommendations in displaying information on the UMN Bulletin application. The questions used to measure user satisfaction are based on the theory of Doll and Torkzadeh [23], namely End-User Computing Satisfaction (EUCS). Thus, in the measurement of user satisfaction, there are five variables measured, that is content, accuracy, format, ease of use, and timeliness [23]. We also used a five-level Likert scale as in [24].

The calculation result of the average percentage score of each variable in the satisfaction test of WSM method implementation in UMN Bulletin application for recommendation of information based on student interest shown in Table 3. 
Table 3: Recapitulation Result of Average Percentage of Testing Variable Score

\begin{tabular}{ccc}
\hline Variable & Percentage of Score & Results \\
\hline Content & $80.41 \%$ & Strongly Agree \\
Accuracy & $79.84 \%$ & Agree \\
Format & $78.78 \%$ & Agree \\
Ease of Use & $79.79 \%$ & Agree \\
Timeliness & $80.51 \%$ & Strongly Agree \\
\hline
\end{tabular}

Based on the five variables, it can be concluded UMN student satisfaction level on the implementation of WSM in UMN Bulletin application to display the recommendation of information based on UMN student interest of $79.87 \%$; it can be interpreted that UMN students are satisfied in using this application.

\section{CONCLUSION}

Weighted Sum Model (WSM) method has been successfully implemented in UMN Bulletin application for information recommendation based on user interest. Interest is based on Holland's theory which divides human into six types. The weight of each interest type is obtained from the percentage when the student first uses the app, and the student can change the weight of each type of interest through the Profile page. The value of information on each interest type is determined when the information is entered into the application. Then the weight of the student's interest will be used to get each total information value. The list of information to be displayed, sorted from the largest amount of information value to the smallest. The result of questionnaires to $156 \mathrm{UMN}$ students, implementation of WSM method in UMN Bulletin application for recommendation of information based on user interest get value equal to $79.87 \%$. With this, it can be concluded that UMN students are satisfied with the implementation of WSM for information recommendations on mobile bulletin applications based on user interest.

In addition, according to the administrators, Content Management System has facilitated in the management of information for students, where the dissemination of information can be done with one application only and the addition of new information can be done anywhere and anytime. The information addition form is also easy to understand even by new users though. Besides, the existence of the Likert scale in information weighting can make UMN students to be boxed based on their interest. The use of recommendations is essential enough to filter and streamline information to suit students.

Based on the research that has been done, there are some suggestions that can be used as input for system development and further research, as follows.

- Based on the result of the test on UMN students, it is expected that the addition of other features, such as seminar registration, event registration, and information based on Student Activity Credit Unit (Satuan Kredit Kegiatan Mahasiswa or SKKM), so that this application can be the main application for non-academic activities.
- The need for a deeper review of the weighting of information on the administrator side. This is based on an interview with Christofer Derian as Public Relation Member of BEM UMN period 2016/2017, so the recommended information could be more accurate.

\section{REFERENCES}

1. Hartono. Dampak Teknologi Informasi Terhadap Penyebaran Informasi di Masyarakat. Visi Pustaka, vol. 4, no. 2, 2002.

2. APJII. Penetrasi dan Perilaku Pengguna Internet Indonesia. [Online]. Available at: https://www.academia.edu/30930899/Penetrasi_dan_Per ilaku_Pengguna_Internet_Indonesia_-_Survei_2016.pdf.

3. A.M. Prestianta, S.B. Nusantara. Identifikasi Pola Penggunaan Perangkat Bergerak Elektronik di Kalangan Mahasiswa Universitas Multimedia Nusantara. Kolase Komunikasi di Indonesia, ASPIKOM. 2017.

4. F. Ricci, L. Rokach, B. Shapira, P. Kantor. Recommender Systems Handbook. New York: Springer. 2011. https://doi.org/10.1007/978-0-387-85820-3

5. M. Kenteris, D. Gavalas, A. Mpitziopoulos. A Mobile Tourism Recommender System. Proceedings of the 15th IEEE Symposium on Computers and Communications, Riccione, Italy. 2010. https://doi.org/10.1109/ISCC.2010.5546758

6. G. Adomavicius, N. Manouselis, Y. Kwon. Multi-Criteria Recommender Systems. Recommender Systems Handbook, Ricci, F., Rokach, L., Shapira, B. \& Kantor, P. (eds.), Boston, MA., Springer, pp. 769-803. 2011. https://doi.org/10.1007/978-0-387-85820-3_24

7. I. Kim, O. de Weck. Adaptive Weighted-sum Method for Bi-objective Optimization: Pareto Front Generation. Structural and Multidisciplinary Optimization, vol. 29, no. 2, pp. 149-158, 2005. https://doi.org/10.1007/s00158-004-0465-1

8. R.T. Marler, J.S. Arora. The weighted sum method for multi-objective optimization: new insights. Structural and Multidisciplinary Optimization, vol. 41, no. 6, pp. 853-862, 2010.

9. J.R.S.C. Mateo. Weighted Sum Method and Weighted Product Method. Multi Criteria Analysis in the Renewable Energy Industry, pp.19-22, 2012.

10. I.P. Stanimirovic, M.Lj. Zlatanovic, M.D. Petkovic. On the Linear Weighted Sum Method for Multi-Objective Optimization. Facta Universitatis (NIS), vol. 26, pp. 49-63, 2011.

11. D. Stanujkic, E.K. Zavadskas. A Modified Weighted Sum Method Based on the Decision-maker's Preferred Levels of Performances. Studies in Informatics and Control, vol. 24, no. 4, pp. 461-469, 2015.

https://doi.org/10.24846/v24i4y201510 
12. L. Allisa. Sistem Rekomendasi Tiket Pesawat Berbasis Android Menggunakan Metode SAW. Thesis, Universitas Sumatera Utara, Indonesia. 2015.

13. R.A. Nugroho. Prototipe Sistem Rekomendasi Menu Makanan dengan Pendekatan Contextual Model dan Multi-Criteria Decision Making. MediaTeknika Jurnal Teknologi, vol. 10, no. 2, pp. 111-121, 2015.

14. D.B.M.M. Fontes, P.A. Pereira, F.A.C.C. Fontes. A Decision Support System for TV self-promotion Scheduling. International Journal of Advanced Trends in Computer Science and Engineering, vol. 8, no. 2, pp. 134-139, 2019. https://doi.org/10.30534/ijatcse/2019/06822019

15. P.M. Soni, V. Paul. A Fuzzy based Data mining Approach for the Loan Credibility Prediction System in Co-operative Banking Sector. International Journal of Advanced Trends in Computer Science and Engineering, vol. 8, no. 3, pp. 815-820, 2019. https://doi.org/10.30534/ijatcse/2019/74832019

16. T. Berka, M. Plößnig. Designing Recommender Systems for Tourism. Proceedings of ENTER, Kairo, Egypt. 2004.

17. S.A. Riskandaria, R. Saptono, Wiharto. Pemanfaatan Metode Simple Additive Weighting (SAW) dalam Penentuan Mahasiswa Berprestasi Tingkat Universitas Sebelas Maret Surakarta. Research Report, Universitas Sebelas Maret. 2014.

18. Hamdani, R. Wardoyo, K. Mustofa. Weighting Model for Group Decision Support System: A Review. Indonesian Journal of Electrical Engineering and Computer Science, vol. 11, no. 3, pp. 962-974, 2018.

19. R.A. Nugroho, R. Ferdiana. Teknik Pemberian Rekomendasi Menu Makanan dengan Pendekatan Contextual Model dan Multi-Criteria Decision Making. Proceedings of CITEE, Yogyakarta, Indonesia, pp. 88-94, 2014.

20. D. Tarsidi. Teori Perkembangan Karir. [Online]. Available at: http://file.upi.edu/Direktori/FIP/ JUR.PEND._LUAR_BIASA/195106011979031-DIDI_ TARSIDI/Makalah\%26Artikel_Tarsidi_PLB/

Teori_Perkembangan_Karir.pdf.

21. D. Brown. Career Choice and Development. New Jersey: John Wiley \& Sons. 2002.

22. A.B. Gunawan, S. Hansun, M.B. Kristanda. Nolong.in: An Android Based Incident Notification Application with Push Notification Technology. International Journal of Electrical and Computer Engineering, vol. 9, no. 1, pp. 485-495, 2019.

https://doi.org/10.11591/ijece.v9i1.pp486-496

23. W.J. Doll, G. Torkzadeh. The Measurement of End-User Computing Satisfaction. MIS Quarterly, vol. 12, no. 2, pp. 259-274, 1988. https://doi.org/10.2307/248851

24. R. Bhalla, Amandeep, P. Jain. A Comparative Analysis of Factor Effecting the Buying Judgement of Smart Phone. International Journal of Electrical and Computer Engineering, vol. 8, no. 5, pp. 3057-3066, 2018.

https://doi.org/10.11591/ijece.v8i5.pp3057-3066 